\title{
PEMUNGUTAN PAJAK DAN PERMASALAHANNYA DI INDONESIA
}

Oleh :

\author{
DR. Niru Anita Sinaga, SH, MH. \\ Dosen Tetap Fakultas Hukum Universitas Dirgantara Marsekal Suryadarma dan \\ Ketua LKBH Fakultas Hukum Universitas Dirgantara Marsekal Suryadarma
}

\begin{abstract}
Abstrak :
Pajak adalah kontribusi wajib kepada negara yang terutang oleh orang pribadi atau badan yang bersifat memaksa berdasarkan undang-undang, dengan tidak mendapatkan imbalan secara langsung dan digunakan untuk keperluan negara bagi sebesar-besarnya kemakmuran rakyat. Untuk mengatur tentang pajak dibutuhkan hukum pajak, yaitu: kumpulan peraturan yang mengatur hubungan antara pemerintah sebagai pemungut pajak dan rakyat sebagai pembayar pajak.

Pemungutan pajak di Indonesia mengalami banyak permasalahan, antara lain disebabkan: Kelemahan regulasi dibidang perpajakan itu sendiri, kurangnya sosialisasi, tingkat kesadaran, pengetahuan dan tingkat ekonomi yang rendah, database yang belum lengkap dan akurat, lemahnya penegakan hukum berupa pengawasan dan pemberian sanksi yang belum konsisten dan tegas.

Untuk mengatasinya dengan melakukan reformasi dibidang perpajakan, antara lain: Melakukan penyempurnaan regulasi/perangkat aturan, menggalakkan sosialisasi agar menambah pengetahuan untuk menumbuhkan kesadaran wajib pajak taat pajak, melakukan evaluasi, menyediakan database yang lengkap, akurat, terintegrasi dan terjamin kerahasiannya, meningkatkan penegakan hukum dalam pengawasan dan pemberian sanksi secara konsisten dan tegas, dan melakukan pemungutan pajak yang: Adil, berdasarkan undang-undang, tidak mengganggu perekonomian, efisien dan sistemnya harus sederhana.
\end{abstract}

Kata kunci: Pajak, Pemungutan Pajak dan Permasalahan.

\begin{abstract}
Taxes are compulsory contributions to the state owed by private persons or entities that are enforceable under the law, by not getting the rewards directly and used for the purposes of the state for the welfare of the people. To regulate the tax law required taxes, namely: a collection of rules that govern the relationship between the government collects the taxes and the people as taxpayers.

Tax collection in Indonesia experienced many problems, partly due: Weakness of regulation in the field of taxation itself, lack of socialization, the level of awareness, knowledge and economic level is low, the database is not yet complete and accurate, weak law enforcement in the form of supervision and sanctions which have not been consistent and firmly.

To cope with the reforms in the field of taxation, among others: Improving regulation / set of rules, encourage socialization in order to increase knowledge to raise awareness of the taxpayer-abiding tax, evaluate, provide a database that is complete, accurate, integrated and assured confidentiality, improve law enforcement in supervision and sanctions consistently and firmly, and perform tax collection: Fair, under the law, do not disrupt the economy, efficient and the system must be simple.
\end{abstract}

Keywords: Tax, Tax Withholding and Problems. 


\section{PENDAHULUAN}

Dalam melaksanakan pembangunan suatu negara memerlukan beberapa unsur pendukung, salah satunya adalah tersedianya sumber penerimaan yang memadai dan dapat diandalkan. Untuk membiayainya, sudah barang tentu (dalam zaman modern ini) dibutuhkan uang. Untuk mendapatkan uang, selain dari mencetak sendiri atau meminjam, dalam zaman modern ini banyak jalan yang ditempuh oleh pemerintah. Sumbersumber penghasilan ini umumnya terdiri dari: Perusahaan-perusahaan, barangbarang milik pemerintah atau yang dikuasai oleh pemerintah, denda-denda dan perampasan-perampasan untuk kepentingan umum, hak-hak waris atas harta peninggalan terlantar, hibah-hibah wasiat dan hibah lainnya, ketiga macam iuran yaitu: pajak, retribusi, dan sumbangan. ${ }^{1}$

Sumber penerimaan ini sangat penting untuk menjalankan kegiatan dari masingmasing tingkat pemerintahan, karena tanpa adanya penerimaan yang cukup maka program-program pemerintah tidak akan berjalan secara maksimal. Salah satu sumber penghasilan negara yang sangat besar adalah dari pajak.

Undang-undang No. 16 Tahun 2009 Tentang Ketentuan Umum dan Tata Cara Perpajakan memberikan definisi: "Pajak adalah kontribusi wajib kepada negara yang terutang oleh orang pribadi atau badan yang bersifat memaksa berdasarkan undang - undang, dengan tidak mendapatkan imbalan secara langsung dan

\footnotetext{
${ }^{1}$ R. Santoso Brotodihardjo, Pengantar Ilmu Hukum Pajak, Bandung: PT. Refika Aditama, Cet ke 21, 2008, hal. 9.
}

digunakan untuk keperluan negara bagi sebesar-besarnya kemakmuran rakyat". ${ }^{2}$

Secara umum "Pajak adalah iuran rakyat kepada kas negara herdasarkan undang- undang (yang dapat dipaksakan) dengan tidak mendapat jasa-jasa timbal (kontra-prestasi), yang langsung dapat ditunjukkan dan yang digunakan untuk membayar pengeluaran umum",

Dari pengertian pajak tersebut baik secara ekonomis maupun secara yuridis dapat ditarik kesimpulan bahwa ciri-ciri tentang pajak antara lain sebagai berikut:

1. Pajak dipungut berdasarkan undangundang, hal ini sesuai dengan perubahan ketiga UUD 1945 Pasal 23A yang menyatakan"pajak dan pungutan lain yang bersifat memaksa untuk keperluan negara diatur dalam undang - undang".

2. Tidak mendapatkan jasa timbal balik (kontraprestasi perseorangan).

3. Pemungutan pajak diperuntukkan bagi keperluan pembiayaan umum pemerintah dalam rangka menjalankan fungsi pemerintahan, baik rutin maupun tidak.

4. Pemungutan pajak dapat dipaksakan.

5. Selain fungsi budgeter (anggaran) juga fungsi regulative (mengatur)

Pajak mempunyai peranan yang sangat penting dalam kehidupan bernegara, khususnya di dalam pelaksanaan pembangunan, merupakan sumber pendapatan negara untuk

\footnotetext{
${ }^{2}$ Undang - undang No. 6 Tahun 1983 Tentang Ketentuan Umum dan Tata Cara Perpajakan Sebagaimana Telah Diubah Dengan Undangundang Nomor 16 Tahun 2009, Bab I pasal 1 angka 1.
} 
membiayai semua pengeluaran termasuk pengeluaran pembangunan.

Berdasarkan hal diatas maka pajak mempunyai beberapa fungsi, yaitu:

a. Fungsi anggaran (budgeter).

b. Fungsi mengatur (regulerend).

c. Fungsi stabilitas.

d. Fungsi redistribusi pendapatan.

Mengingat pentingnya pajak sebagai sumber pendapatan negara maka dibutuhkan suatu aturan atau hukum yang mengatur tentang perpajakan yang disebut hukum pajak. Secara umum, hukum pajak adalah kumpulan peraturan yang mengatur hubungan antara pemerintah sebagai pemungut pajak dan rakyat sebagai pembayar pajak, didalamnya mengatur hak dan kewajiban masing-masing pihak.

Dengan adanya peraturan atau hukum yang mengatur tentang pajak, maka diharapkan penerimaan pajak sebagai sumber utama pembiayaan Anggaran Pendapatan dan Belanja Negara (APBN) dapat memperoleh hasil maksimal dan dapat dipertahankan secara berkesinambungan. Namun kenyataannya pemungutan pajak ini masih banyak menimbulkan permasalahanpermasalahan, antara lain disebabkan: Kelemahan regulasi dibidang perpajakan itu sendiri, kurangnya sosialisasi, tingkat kesadaran, pengetahuan dan tingkat ekonomi yang rendah, database yang belum lengkap dan akurat, lemahnya penegakan hukum berupa pengawasan dan pemberian sanksi yang belum konsisten dan tegas. Selain itu, kendala lain dalam pemungutan pajak adalah adanya paradigma yang selama ini dianut oleh sebagian besar masyarakat bahwa percuma membayar pajak karena akan memperkaya petugas pajak. Tindakan seperti ini dilakukan masyarakat untuk meloloskan diri dari pajak dan merupakan usaha yang disebut perlawanan terhadap pajak. Perlawanan ini terbagi manjadi dua, yaitu: Perlawanan pasif dan Perlawanan aktif.

Untuk mengatasi permasalahan atau kendala tersebut, maka pemerintah harus dapat: M Menunjukkan kepada publik bahwa pengelolaan pajak dilakukan dengan baik dan benar, menyiapkan pengelolaan data yang lengkap, akurat, terintegrasi dan terjamin kerahasiannya (database management system), penyempurnaan perangkat aturan, melaksanakan penegakkan hukum secara konsisten dan tegas, Fiskus harus melayani Wajib Pajak secara professional, sosialisasi yang bersifat kontinyu, Dirjen pajak perlu membentuk suatu team work guna mencari isu-isu strategis yang berkembang dan melakukan evaluasi terhadap isu tersebut (faktor ekternal), inovasi dalam palayanan, seperti kemudahan dan kenyamanan dalam mengurus pajak, syarat-syarat pemungutan pajak harus didasarkan : Pemungutan pajak harus adil, tidak menggangu perekonomian, Apabila langkah ini telah dilakukan, maka kepercayaan masyarakat pun meningkat, kemudian masyarakat akan tergerak hatinya untuk menyisihkan sebagian hartanya kapada negara dalam bentuk membayar pajak. Dengan adanya kesadaran dan kepatuhan Wajib Pajak merupakan salah satu kunci keberhasilan pemerintah dalam menghimpun penerimaan pajak sehingga penerimaan negara dapat berkesinambungan.

\section{PERMASALAHAN}

1. Permasalahan-permasalahan apa saja yang dihadapi dalam pemungutan pajak di Indonesia? 
2. Bagaimana upaya untuk mengatasi permasalahan pemungutan pajak di Indonesia?

\section{PEMBAHASAN}

\section{A. Tinjauan Umum Tentang Pajak}

\section{Pengertian pajak}

N. J. Feldmann dalam bukunya De overheidsmiddelen van Indonesia, Leiden, 1949, berbunyi: "Belastingen zijn aan de Overheid (volgens algemene, door haar vastgestelde normen) verschuldigdeafdwingbareprestties, waargeen tegenprestatie tegenover staat en uitsluitend dienen tot dekking vanpublieke uitgaven $^{3}$

("Pajak adalah prestasi yang dipaksakan sepihak oleh dan terutang kepada penguasa (menurut normanorma yang ditetapkannya secara umum), tanpa adanya kontraprestasi, dan semata-mata digunakan untuk menutup pengeluaran-pengeluaran umum".) Feldmann (seperti juga halnya dengan Seligman) berpendapat, bahwa terhadap pembayaran pajak, tidak ada kontraprestasi dari negara.

M. J. H. Smeets dalam bukunya De Economische Betekenis der Belastingen, 1951, berbunyi: "Belastingen zijn aan de overheid (volgens normen) verschuligde, afdwingbare pretties, zonder dat hiertegenover, in het individuele geval, aanwijsbare tegen-prestaties staan; zij strekken tot dekking van publieke uitgaven". 4

("Pajak adalah prestasi kepada pemerintah yang terutang melalui

${ }^{3}$ Erly Suandy, Hukum Pajak, Edisi 5, Jakarta:

Salemba Empat, 2011, hal. 8.

${ }^{4}$ Ibid norma-norma umum, dan yang dapat dipaksakan, tanpa ada kalanya kontraprestasi yang dapat ditunjukkan dalam hal yang individual; maksudnya adalah untuk membiayai pengeluaran pemerintah".)

P.J.A. Adriani dalam R. Santoso Brotodihardjo, dikemukakan sebagai berikut "Pajak adalah iuran kepada negara (yang dapat dipaksakan) yang terutang oleh yang wajib membayarnya menurut peraturanperaturan, dengan tidak mendapat prestasi-kembali, yang langsung dapat ditunjuk, dan yang gunanya adalah untuk membiayai pengeluaranpengeluaran umum berhubung dengan tugas negara untuk menyelenggarakan pemerintahan".

Sommerfeld, memberikan pengertian bahwa: "pajak adalah suatu pengalihan sumber-sumber yang wajib dilakukan dari sektor swasta kepada sektor pemerintah berdasarkan peraturan tanpa suatu imbalan kembali yang langsung dan seimbang, agar pemerintah dapat melaksanakan tugas-tugasnya dalam menjalankan pemerintahan"6.

Rochmat Soemitro, dalam bukunya Dasar-Dasar Hukum Pajak dan Pajak Pendapatan adalah sebagai berikut: "Pajak adalah iuran rakyat kepada kas negara herdasarkan undang undang (yang dapat dipaksakan) dengan tidak mendapat jasa-jasa timbal (kontra-prestasi), yang langsung dapat ditunjukkan dan yang

\footnotetext{
${ }^{5}$ R. Santoso Brotodihardjo, Op.Cit., hal. 2.

${ }^{6}$ Muqodim, Perpajakan Buku Satu, Yogyakarta: UII Press, 1999, hal. 1.
} 
digunakan untuk membayar pengeluaran umum", dengan penjelasan sebagai berikut: "dapat dipaksakan" artinya: bila utang pajak tidak dibayar, utang itu dapat ditagih dengan menggunakan kekerasan, seperti surat paksa dan sita, dan juga penyanderaan; terhadap pembayaran pajak, tidak dapat ditunjukkan jasa timbal balik tertentu, seperti halnya dengan retribusi. ${ }^{7}$ Definisinya yang kemudian dipertahankan (sebagai koreksi dari bagian pertama dari definisinya semula) dapat disimpulkan dari uraian bukunya yang berjudul: Pajak dan Pembangunan, Eresco, 1974, hal. 8. Definisi tersebut kurang lebih dapat berbunyi sebagai berikut: Pajak adalah peralihan kekayaan dari pihak rakyat kepada Negara untuk membiayai pengeluaran rutin dan "surplus"-nya digunakan untuk public saving yang merupakan sumber utama untuk membiayai public investment. ${ }^{8}$

Undang-undang No. 6 Tahun 1983 Tentang Ketentuan Umum dan Tata Cara Perpajakan sebagaimana telah diubah dengan Undang-undang Nomor 16 Tahun 2009, memberikan definisi "Pajak adalah kontribusi wajib kepada negara yang terutang oleh orang pribadi atau badan yang bersifat memaksa berdasarkan undang- undang, dengan tidak mendapatkan imbalan secara langsung dan digunakan untuk keperluan negara bagi sebesar-besarnya kemakmuran rakyat". ${ }^{9}$

${ }^{7}$ R. Santoso Brotodihardjo, Op.Cit., hal. 6.

${ }^{8} \mathrm{Ibid}$.

${ }^{9}$ Undang-undang No. 6 Tahun 1983 Tentang

Ketentuan Umum dan Tata Cara Perpajakan

Sebagaimana Telah Diubah Dengan Undangundang Nomor 16 Tahun 2009, Op.Cit.
Dari definisi-definisi diatas, yang menjadi riri-ciri pajak adalah sebagai berikut.

a. Pajak peralihan kekayaan dari orang / badan ke pemerintah.

b. Pajak dipungut berdasarkan /dengan kekuatan undang-undang serta aturan pelaksanaannya, sehingga dapat dipaksakan.

c. Dalam pembayaran pajak tidak dapat ditunjukkan adanya kontaprestasi langsung secara individual yang diberikan oleh pemerintah.

d. Pajak dipungut oleh negara baik oleh pemerintah pusat maupun pemerintah daerah.

e. Pajak diperuntukkan bagi pengeluaran-pengeluaran

pemerintah, yang bila dari pemasukannya masih terdapat surplus, dipergunakan untuk membiayai public investment.

f. Pajak dapat digunakan sebagai alat untuk mencapai tujuan tertentu dari pemerintah.

g. Pajak dapat dipungut secara langsung atau tidak langsung.

\section{Kebijakan fiskal}

Dalam perekonomian kontemporer komponen pendapatan pajak sebagai bagian dari kebijakan fiskal dipandang sebagai kebijakan yang memiliki peranan dan pengaruh yang sangat signifikan dalam pembangunan ekonomi terutama karena hal-hal berikut ini. ${ }^{10}$

a. Adanya Pajak merupakan piranti yang penting di dalam mengekang permintaan yang semakin

${ }^{10}$ Erly Suandy,op. cit, hal. 13-14. 
meningkat terhadap barang-barang konsumsi yang ditimbulkan oleh proses pembangunan.

b. Perpajakan tidak hanya bertujuan untuk mendapatkan penerimaan yang lebih besar, namun juga berperan sebagai perangsang untuk menabung dan melakukan investasi.

c. Untuk mentransfer sumber daya manusia kepada pemerintah agar digunakan lebih produktif.

d. Perpajakan harus memperbaiki pola investasi di dalam perekonomian.

e. Salah satu tujuan perpajakan adalah untuk mengurangi jurang perbedaan pendapat si kaya dan si miskin.

f. Perpajakan harus memobilisasikan surplus ekonomi untuk pembangunan secara berkesinambungan.

\section{Fungsi pajak}

Fungsi pajak menurut Rochmat Soemitro ada 3, yaitu : Fungsi Budgeter; fungsi mengatur dan untuk menanggulangi inflasi. ${ }^{11}$

Secara umum fungsi pajak yang dikenakan kepada masyarakat mempunyai 4 (empat) fungsi, yaitu :

a. Fungsi finansial (budgeter), pajak sebagai sumber dana bagi pemerintah untuk membiayai pengeluaran-pengeluaran pemerintahan.

b. Fungsi mengatur (regulerend), pajak sebagai alat untuk mengatur atau

${ }^{11}$ Rochmat Soemitro, Pengantar Singkat Hukum Pajak, Cetakan-2, Bandung : PT. Eresco, 1988 hal .2-3. melaksanakan kebijakan pemerintah dalam bidang sosial dan ekonomi. Contoh: pajak yang tinggi terhadap minuman keras guna untuk mengurangi konsumsi minuman keras.

c. Fungsi stabilitas, dengan adanya pajak pemerintah memiliki dana untuk menjalankan kebijakan yang berhubungan dengan stabilitas harga sehingga inflasi dapat dikendalikan. Hal ini bisa dilakukan antara lain dengan jalan mengatur peredaran uang di masyarakat, pemungutan pajak, penggunaan pajak yang efektif dan efisien.

d. Fungsi redistribusi pendanaan, pajak yang sudah dipungut oleh negara akan digunakan untuk membiayai semua kepentingan umum, termasuk juga untuk membiayai pembangunan, sehingga dapat membuka kesempatan kerja yang pada akhirnya akan dapat meningkatkan pendapatan masyarakat. ${ }^{12}$

\section{Pembagian pajak}

Pembagian pajak dapat dilakukan berdasarkan golongan, wewenang pemungut, maupun sifatnya: ${ }^{13}$

a. Menurut golongannya

1) Pajak langsung, adalah pajak yang bebannya harus ditanggung sendiri oleh wajib pajak yang bersangkutan dan tidak dapat dialihkan kepada pihak lain misalnya: pajak penghasilan. Pajak penghasilan

\footnotetext{
${ }^{12}$ Fidel, Pajak Penghasilan. Jakarta: Carofin Publishing, 2008, hal .3.
}

${ }^{13}$ Erly Suandy, Op. Cit, hal. 35-39. 
adalah pajak yang dikenakan terhadap penghasilan, dapat dikenakan secara berkala dan berulang-ulang dalam jangka waktu tertentu baik masa pajak maupun tahun pajak.

2) Pajak tidak langsung, adalah pajak yang bebannya dapat dialihkan atau digeserkan kepada pihak lain sehingga sering disebut juga sebagai pajak tidak langsung.. Contohnya : Pajak pertambahan nilai dan Pajak Penjualan atas Barang Mewah. Dalam pajak ini beban pajak digeserkan dari produsen/penjual ke pembeli/konsumen, karena pergeseran ini searah dengan arus barang yaitu dari produsen ke konsumen maka pergeserannya disebut pergeseran kedepan (forward shifting). Disamping itu ada juga yang disebut dengan pergeseran kebelakang (backward shifting) yaitu pergeseran pajak yang berlawanan dengan arus barang.

b. Berdasarkan wewenang pemungut

1) Pajak pusat/negara, adalah pajak yang wewenang pemungutannya ada pada pemerintah pusat yang pelaksanaannya dilakukan oleh Departemen Keuangan melalui Direktorat Jenderal Pajak. Pajak pusat diatur dalam undang-undang dan hasilnya akan masuk ke Anggaran Pendapatan dan Belanja Negara (APBN). Pajak pusat/pajak negara sebagai berikut: Pajak Penghasilan, Pajak Pertambahan Nilai dan Pajak Penjualan atas Barang Mewah,
Pajak Bumi dan Bangunan, Bea Materai, Bea Perolehan Hak atas Tanah dan Bangunan.

2) Pajak daerah, adalah pajak yang wewenang pemungutannya ada pada pemerintah daerah yang pelaksanaannya dilakukan oleh Dinas Pendapatan Daerah. Pajak propinsi, contohnya: Pajak Kendaran Bermotor dan Kendaraan Diatas Air, Bea balik nama kendaraan bermotor dan kendaraan diatas air, dan lainlain.Pajak daerah kabupaten / kota, contohnya: Pajak hotel, pajak restoran, dan lain-lain.

c. Menurut sifatnya

1) Pajak subyektif, adalah pajak yang memperhatikan kondisi /keadaan Wajin Pajak. Dalam menentukan pajaknya harus ada alasan-alasan objektif yang berhubungan erat dengan keadaan materialnya, yaitu gaya pikul. Gaya pikul adalah kemampuan Wajib Pajak memikul pajak setelah dikurangi biaya hidup minimum, contoh: Pajak Penghasilan.

2) Pajak obyektif, adalah pajak yang pada awalnya memperhatikan objek yang menyebabkan timbulnya kewajiban membayar, kemudian baru dicari subjeknya baik orang pribadi maupun badan. Jadi dengan perkataan lain pajak objektif adalah pengenaan pajak yang hanya memperhatikan objeknya saja.

\section{Syarat pemungutan pajak}

Agar pemungutan pajak tidak menimbulkan hambatan atau perlawanan, maka pemungutan pajak 
harus memenuhi syarat pemungutan pajak, antara lain :

a. Syarat keadilan. Pemungutan pajak harus adil sesuai dengan tujuan hukum yakni mencapai keadilan berdasarkan undang-undang dan peraturan lain dalam mengenakan pajak secara umum dan merta, serta disesuaikan dengan kemampuan masing-masing. Sedangkan adil dalam pelaksanannya yakni dengan memberikan hak bagi Wajib Pajak untuk mengajukan keberatan ke Kepala Kantor Pelayanan Pajak setempat, dan mengajukan banding ke Pengadilan Pajak.

b. Syarat yuridis. Pemungutan pajak harus berdasarkan undang-undang.

c. Syarat ekonomis. Pemungutan pajak tidak boleh menganggu kelancaran kegiatan perekonomian, baik produk maupun perdagangan, sehingga tidak menimbulkan kelesuan perekonomian masyarakat.

d. Syarat finansial. Pemungutan pajak harus efisien sesuai fungsi budgetair. Biaya pemungutan pajak harus dapat ditekan sehingga lebih rendah dari hasil pemungutanya.

e. Sistem pemungutan pajak harus sederhana. Sistem pemungutan pajak yang sederhana akan memudahkan dan mendorong masyarakat dalam memenuhi kewajiban perpajakan. ${ }^{14}$

\section{Sistem pemungutan pajak}

Wirawan B. Ilyas dan Richard Burton dalam bukunya Hukum Pajak

${ }^{14}$ Mardiasmo, Perpajakan Edisi Revisi,

Yogyakarta: CV Andy Offset, 2008, hal. 2. menyatakan bahwa pada dasarnya ada 4 (empat) macam sistem pemungutan pajak yaitu :

a. Official assessment system adalah suatu pemungutan pajak yang memberi menentukan besarnya pajak yang harus dibayar (pajak yang terutang) oleh seseorang. Dengan sistem ini masyarakat (Wajib Pajak) bersifat pasif dan menunggu dikeluarkannya suatu ketetapan pajak oleh Fiskus. Besarnya utang pajak seseorang baru diketahui setelah adanya surat ketetapan pajak.

b. Semi self assessment system adalah suatu system pemungutan pajak yang memberi wewenang pada fiskus dan Wajib Pajak untuk menentukan besarnya pajak seseorang yang terutang. Dalam sistem ini setiap awal tahun pajak Wajib Pajak menentukan sendiri besarnya pajak yang terutang untuk tahun berjalan yang merupakan angsuran bagi Wajib Pajak yang harus disetor sendiri. Baru kemudian pada akhir tahun pajak Fiskus menentukan besarnya uatang pajak yang sesungguhnya berdasarkan data yang dilaporkan oleh Wajib Pajak.

c. Self assessment system adalah suatu system pemungutan pajak yang memberi wewenang penuh kepada Wajib Pajak untuk menghitung, memperhitungkan, menyetorkan, dan melaporkan sendiri besarnya utang pajak. Dalam sistem ini Wajib Pajak yang aktif sedangkan Fiskus tidak turut campur dalam penentuan besarnya pajak yang terutang seseorang, kecuali Wajib Pajak melanggar ketentuan yang berlaku. 
d. Withholding system adalah suatu system pemungutan pajak yang memberi wewenang pada pihak ketiga untuk memotong/ memungut besarnya pajak yang terutang. Pihak ketiga yang telah ditentukan tersebut selanjutnya menyetor dan melaporkannya kepada Fiskus. Pada sistem ini Fiskus dan Wajib Pajak tidak aktif, Fiskus hanya bertugas mengawasi saja pelaksanaan pemotongan/ pemungutan yang dilakukan oleh pihak ketiga. ${ }^{15}$

Dasar hukum pemungutan pajak adalah perubahan ketiga UUD 1945 Pasal 23A. Lembaga pemerintah yang mengelola perpajakan negara di Indonesia adalah Direktorat Jenderal Pajak (DJP) yang merupakan salah satu Direktorat Jenderal yang ada di bawah naungan Departemen Keuangan Republik Indonesia.

\section{Asas dan teori pemungutan pajak}

Untuk mencapai tujuan tersebut, maka pemungutan pajak didasarkan pada: ${ }^{16}$

a. Asas keadilan. Dalam mencari keadilan, salah satu jalan yang harus ditempuh ialah mengusahakan agar supaya pemungutan pajak diselenggarakan secara umum dan merata. Berkaitan dengan pemungutan pajak, Smith (1723-1790) dalam Santoso menguraikan asas

${ }^{15}$ Wirawan B.Ilyas \& Richard Burton, Hukum Pajak Edisi 3, Jakarta: Salemba Empat, 2007, hal. 22.

${ }^{16}$ R. Santoso Brotodihardjo, Op.Cit., hal . 26-

27. pemungutan pajak yang lebih dikenal dengan The Four Maxims, dengan uraian sebagai berikut: ${ }^{17}$

1) Pembagian tekanan pajak di antara Subjek Pajak masingmasing hendaknya dilakukan seimbang dengan kemampuannya, yaitu seimbang dengan penghasilan yang dinikmatinya masing-masing, di bawah perlindungan pemerintah (asas pembagian/asas kepentingan). Dalam asas "equality" ini tidak diperbolehkan suatu negara mengadakan diskriminasi di antara sesama wajib pajak, dalam keadaan yang sama, para Wajib Pajak harus dikenakan pajak yang sama pula;

2) Pajak yang harus dibayar oleh seseorang harus terang (certain) dan tidak mengenal kompromis (not arbitrary). Dalam asas "certainty" ini, kepastian hukum yang dipentingkan adalah yang mengenai subjek, objek, besarnya pajak, dan juga ketentuan mengenai waktu pembayarannya;

3) "Every tax ought to be levied at the time, or in the manner, in which it is most likely to be convenient for the contributor to pay it". Teknik pemungutan pajak yang dianjurkan ini (yang juga disebut "convenience of payment") menetapkan bahwa pajak hendaknya dipungut pada saat yang paling baik bagi para Wajib Pajak, yaitu saat sedekatdekatnya dengan detik

${ }^{17} \mathrm{Ibid}$, hal. 27-28. 
diterimanya penghasilan yang bersangkutan;

4) Every tax ought to be so contrived as both to take out and to keep out of the pockets of the people as little as possible over and above what it brings into to public treasury of the State". Asas efisiensi ini menetapkan bahwa pemungutan pajak hendaknya dilakukan sehemat-hematnya; jangan sekali-kali biaya pemungutan melebihi pemasukan pajaknya.

b. Asas menurut falsafah hukum

Di atas telah diuraikan bahwa hukum pajak harus mengabdi kepada keadilan. Keadilan inilah yang kita namakan "asas pemungutan pajak". Lepas dari kenyataan bahwa pada pelaksanaannya pembuat undangundang pajak harus selalu memegang teguh kepada asas keadilan, seringkali juga dipersoalkan, apakah pemungutan pajak oleh suatu negara berdasarkan pula atas keadilan. Sejak abad ke-18 timbullah teoriteori guna memberikan dasar menyatakan keadilan (justification) kepada hak negara untuk memungut pajak dari rakyatnya, antara lain :

1) Teori asuransi (Verzerings theory) Teori ini menyatakan bahwa termasuk dalam tugas negara untuk melindungi orang dan segala kepentingannya, keselamatan dan keamanan jiwa, juga harta bendanya.

2) Teori kepentingan (Belangen theory) Teori ini dalam ajarannya yang semula, hanya memperhatikan pembagian beban pajak yang harus dipungut dari penduduk seluruhnya. Pembagian beban ini harus didasarkan atas kepentingan orang masingmasing dalam tugas-tugas pemerintah (yang bermanfaat baginya), termasuk juga perlindungan atas jiwa orangorang itu beserta harta bendanya.

3) Teori gaya pikul. Yang menjadi pokok pangkal teori ini pun adalah asas keadilan, yaitu tekanan pajak itu haruslah sama beratnya untuk setiap orang.

4) Teori kewajiban pajak mutlak atau teori bakti. berlawanan dengan ketiga teori di atas, yang tidak mengutamakan kepentingan-kepentingan negara di atas kepentingan warganya, maka teori ini berdasarkan atas paham Organische Staatsleer, sehingga diajarkanlah olehnya bahwa justru karena sifat negara inilah maka timbullah hak mutlak untuk memungut pajak.

5) Teori asas gaya beli.Teori ini mengajarkan, bahwa penyelenggaraan kepentingan masyarakat inilah yang dapat dianggap sebagai dasar keadilan pemungutan pajak; bukan kepentingan individu, juga bukan kepentingan negara, melainkan kepentingan masyarakat yang meliputi keduanya itu. ${ }^{18}$

c. Asas yuridis. Hukum pajak harus dapat memberi jaminan hukum yang perlu untuk menyatakan keadilan yang tegas, baik untuk negara maupun untuk warganya.

${ }^{18} \mathrm{Ibid}$, hal. 29-37. 
Maka mengenai pajak di negara hukum segala sesuatu harus ditetapkan pengenaan dan pemungutan pajak (termasuk bea dan cukai) untuk keperluan negara hanya boleh terjadi berdasarkan undang-undang. ${ }^{19}$

d. Asas ekonomi. Selain fungsi budgeter, pajak juga dipergunakan sebagai alat untuk menentukan politik perekonomian. Tidak mungkin suatu negara menghendaki merosotnya kehidupan ekonomi masyarakat. ${ }^{20}$

e. Asas finansial. Sesuai dengan sistem budgeternya, bahwa sudah barang tentu bahwa biaya-biaya untuk mengenakan dan untuk memungutnya harus sekecilkecilnya apalagi dalam bandingan dengan pendapatannya. ${ }^{21}$

\section{B. Tinjauan Umum Tentang Hukum Pajak}

\section{Pengertian hukum pajak}

Menurut R. Santoso Brotodihardjo: "Hukum pajak yang disebut hukum fiskal adalah keseluruhan dari peraturanperaturan yang meliputi wewenang pemerintah untuk mengambil kekayaan seseorang dan menyerahkannya kembali kepada masyarakat dengan melalui kas negara, sehingga ia merupakan bagian dari hukum publik, yang mengatur hubungan-hubungan hukum antara negara dan orangorang atau badan-badan (hukum) yang berkewajiban membayar

${ }^{19}$ Ibid, hal. 37.

${ }^{20} \mathrm{Ibid}$, hal. 41-42.

${ }^{21} \mathrm{Ibid}$, hal. 42. pajak (selanjutnya disebut sebagai Wajib Pajak)." ${ }^{22}$

Menurut Rochmat Soemitro menyatakan bahwa: "Hukum pajak ialah suatu kumpulan peraturan yang mengatur hubungan antara pemerintah sebagai pemungut pajak dan rakyat sebagai pembayar pajak". Hukum pajak menerangkan: siapa Wajib Pajak (subyek) dan apa kewajibankewajiban mereka terhadap pemerintah, hak-hak pemerintah, obyek-obyek apa yang dikenakan pemerintah, cara penagihan, cara pengajuan keberatan-keberatan, dan sebagainya. ${ }^{23}$

\section{Pembedaan hukum pajak}

Hukum Pajak dapat dibedakan menjadi 2 (dua), yaitu hukum pajak material dan hukum pajak formal. Hukum pajak material. Hukum pajak material adalah hukum pajak yang memuat normanorma yang menerangkan keadaan, perbuatan, dan peristiwa hukum yang harus dikenakan pajak atau dapat dikatakan pula segala sesuatu tentang timbulnya, besarnya, dan hapusnya utang pajak, serta hubungan hukum antara pemerintah dan Wajib Pajak, yaitu mengenai Subjek Pajak, Wajib Pajak, Obyek Pajak dan tarif. Hukum pajak formal. Hukum pajak formal ialah hukum pajak yang memuat peraturanperaturan mengenai cara-cara hukum pajak material menjadi kenyataan. antara lain adalah

${ }^{22}$ Ibid, hal. 1.

${ }^{23}$ Mustaqiem, Pajak Daerah dalam Transisi Otonomi Daerah, Jakarta: FH UII Press, 2008, hal. 230. 
mengenai surat pemberitahuan, surat ketetapan pajak, surat tagihan, pembukuan, surat keberatan /minta banding, pembayaran /penagihan pajak (dengan paksa), cara menghitung pajak, sanksi administrasi, ketentuan hukum pidana, penyidikan dan lain-lain. ${ }^{24}$

\section{Permasalahan-Permasalahan Dalam Pemungutan Pajak di Indonesia}

Undang-undang yang mengatur tentang perpajakan sudah dibentuk dan diberlakukan di Indonesia, namun masih ditemukan banyak permasalahan atau kendala mendasar dalam pelaksanaannya. Hal ini sangat mempengaruhi hasil penerimaan pajak sebagai sumber pendapatan negara. Berbagai kendala disebabkan berbagai faktor yang akan diuraikan secara garis besar dibawah ini.

Kurangnya sosialisasi dari pemerintah kepada masyarakat sebagai Wajib Pajak mengenai pentingnya membayar pajak, manfaat membayar pajak, dan sanksi yang akan diterima apabila Wajib Pajak melalaikan kewajibannya. Disamping kesadaran pengetahuan Sumber Daya Manusia (SDM) masih rendah juga ikut mempengaruhi, dimana Wajib Pajak belum memahami tentang pentingnya membayar pajak tersebut, belum mengetahui bagaimana prosedur pendaftaran, menghitung dan melaporkan sendiri Obyek Pajak

${ }^{24}$ Jajat Djuhadiat S, Modul DPT III Pengantar Hukum Pajak, Jakarta : Departemen KeuanganBPLK, 1993, hal. 15. yang dikuasai, dimiliki dan dimanfaatkannya.

Tingkat ekonomi sebahagian Wajib Pajak yang sangat rendah sangat mempengaruhi, dimana Wajib Pajak masih lebih memprioritaskan biaya yang sifatnya mendasar, seperti: Biaya sekolah, biaya kesehatan dan sebagainya, dari pada membayar pajak.

Database yang masih jauh dari standar Internasional. Padahal database sangat menentukan untuk menguji kebenaran pembayaran pajak dengan sistem self assessment. Kondisi seperti ini menyulitkan riset empiris yang bertujuan menguji kepatuhan Wajib Pajak. Wajib Pajak dapat memberikan informasi dan melaporkan yang tidak sesuai dengan kondisi yang sebenarnya. Database yang lengkap dan akurat berpengaruh terhadap efektivitas pelaksanaan penegakan hukum dan juga kepatuhan wajib pajak. Selanjutnya kepatuhan wajib pajak berpengaruh pada penerimaan pajak.

Kurangnya atau tidak adanya kesadaran masyarakat sebagai Wajib Pajak untuk membayar pajak ke negara adalah sebagai bentuk perlawanan. Persepsi Wajib Pajak bahwa percuma membayar pajak dengan tertib, karena pada akhirnya akan digunakan secara boros dan tidak tepat sasaran bahkan akan dikorup oleh sebahagian dari pegawai pajak. Tingkat kepatuhan Wajib Pajak yang masih rendah akan menimbulkan selisih antara jumlah pajak yang dibayar oleh Wajib Pajak dengan jumlah pajak yang seharusnya dibayar semakin besar. Wajib Pajak 
yang memiliki penghasilan besar cenderung untuk lebih patuh ketimbang yang berpenghasilan rendah karena yang berpenghasilan besar cenderung untuk lebih konservatis dalam pelaporan kewajiban perpajakannya. Penerapan tarif pajak yang tinggi menjadi kendala juga, karena memberatkan Wajib Pajak.

Kendala lain adalah: Peraturan pelaksana undang-undang sering tidak konsisten dengan undangundang; bayaknya pungutan resmi dan tidak resmi baik di pusat maupun di daerah; lemahnya penegakan hukum (law enforcement); birokrasi yang berbelit-belit dan sebagainya yang seharusnya bila dilakukan dengan baik tentu membantu dalam mewujudkan good governance dalam bentuk pemerintahan yang bersih dan berwibawa. Adanya Perlawanan terhadap pajak adalah hambatanhambatan yang ada atau terjadi dalam upaya pemungutan pajak. Perlawanan pajak dapat dibedakan menjadi dua bagian, adalah sebagai berikut.

1. Perlawanan Pasif. Perlawanan pajak secara pasif ini berkaitan erat dengan keadaa,n sosial ekonomi masyarakat di negara yang bersangkutan. Pada umumnya masyarakat tidak melakukan suatu upaya yang sistematis dalam rangka menghambat penerimaan negara, tetapi lebih dikarenakan oleh kebiasan-kebiasaan yang berlaku dalam masyarakat tersebut. Misalnya: kebiasaan masyarakat desa yang menyimpan uang di rumah atau dibelikan emas bukanlah mereka menghindari Pajak Penghasilan dari bunga tetapi karena belum terbiasa dengan perbankan.

2. Perlawanan Aktif. Perlawanan pajak secara aktif ini merupakan serangkaian usaha yang dilakukan oleh Wajib Pajak untuk tidak membayar pajak atau mengurangi jumlah pajak yang seharusnya dibayar.

Perlawanan secara aktif dapat dibagi menjadi dua, adalah sebagai berikut.
a. Penghindaran pajak (tax avoidance).
b. Penggelapan pajak (tax evasion).

\section{Penghindaran Pajak.}

Penghindaran pajak (tax avoidance) adalah suatu usaha pengurangan secara legal yang dilakukan dengan cara memanfaatkan ketentuanketentuan di bidang perpajakan secara optimal seperti, pengecualian dan pemotonganpemotongan yang diperkanankan maupun manfaat hal-hal yang belum diatur dan kelemahankelemahan yang ada dalam peraturan perpajakan yang berlaku.

4. Penggelapan Pajak. Penggelapan pajak (tax evasion) adalah merupakan pengurangan pajak yang dilakukan dengan melanggar peraturan perpajakan seperti memberi data-data palsu atau menyembunyikan data. Dengan demikian, penggelapan pajak dapat dikenakan sanksi pidana. 
D. Upaya - Upaya Yang Dilakukan Dalam Mengatasi Permasalahan Pajak di Indonesia

Dalam rangka menjamin kesinambungan penerimaan pajak sebagai sumber utama APBN dan memberikan keadilan dalam berusaha (level of playingfields), pemerintah perlu memperluas basis pajak dengan meningkatkan jumlah wajib pajak yang terdaftar untuk memiliki NPWP dan sekaligus kepatuhannya. Pemerintah akan terus berupaya menggali potensi pajak (tax coverage) seoptimal mungkin dan juga meningkatkan kepatuhan wajib pajak (taxpayers' compliance). Untuk mengatasi permasalahan diatas maka pemerintah melakukan apa yang disebut reformasi Pajak. Dalam hal ini pemerintah melakukan berbagai upaya dengan mengeluarkan serangkaian undang-undang untuk mengubah undang-undang yang telah ada.

Hal ini dilakukan untuk lebih memberikan rasa keadilan dan kepastian hukum. Tujuan dari penyempurnaan undang-undang pajak adalah dalam rangka ekstensifikasi dan intesifikasi pengenaan dan pemungutan pajak yang sekaligus merupakan upaya peningkatan keadilan beban pajak, penghapusan fasilitas pajak yang tidak memiliki landasan hukum yang akan merugikan perekonomian nasional dan menutup peluang-peluang penghindaran pajak (loopholes). Untuk itu sesuai dengan fungsi regulerend secara umum dapat dinyatakan bahwa sistem pajak harus dapat mendorong kegiatan dan pertumbuhan ekonomi nasional dengan mendorong investasi dari luar serta mengamankan penerimaan negara. Sedangkan untuk menjalankan fungsi budgeter sebagai pilar utama penerimaan negara dilakukan dengan memperluas cakupan subjek dan objek pajak, dan meminimalkan kemungkinan transfer pricing dan pembatasan pengenaan Pajak Penghasilan final. Semua kebijakan ini dalam jangka panjang diharapkan dapat meningkatkan tax compliance, meningkatkan investasi dan penerimaan negara untuk menuju kemandirian pembiayaan pembangunan.

Menggalakkan penyuluhanpenyuliuhan di bidang perpajakan. Hal ini dilakukan untuk menambah wawasan dari wajib Pajak. Dengan bertambahnya pengetahuan diharapkan menimbulkan kesadaran untuk membayar pajak. Dengan demikian diharapkan penerimaan negara melalui sektor pajak dapat bertambah. Memperbaiki budaya hukum baik bagi wajib Pajak maupun Petugas Pajak . Para pihak diharapkan dapat melakukan kewajiban masingmasing sesuai dengan ketentukan perpajakan yang berlaku. Pemerintah harus melakukan Pengawasan yang ketat terhadap Pemungutan Pajak. Apabila ditemukan penyimpangan maka harus diberikan sanksi yang tegas. Hal ini diperlukan untuk memberikan efek jera bagi pihak wajib Pajak maupun Petugas Pajak.

\section{PENUTUP}

\section{Kesimpulan dan Saran}

\section{Kesimpulan}

a. Dengan adanya peraturan atau hukum yang mengatur tentang pajak, maka diharapkan penerimaan 
pajak sebagai sumber utama pembiayaan Anggaran Pendapatan dan Belanja Negara (APBN) dapat memperoleh hasil maksimal dan dapat dipertahankan secara berkesinambungan. Namun kenyataannya pemungutan pajak ini masih banyak menimbulkan permasalah, antara lain disebabkan: Kelemahan regulasi dibidang perpajakan itu sendiri, kurangnya sosialisasi, tingkat kesadaran, pengetahuan dan tingkat ekonomi yang rendah, database yang belum lengkap dan akurat, lemahnya penegakan hukum berupa pengawasan dan pemberian sanksi yang belum konsisten dan tegas. Selain itu, kendala lain dalam pemungutan pajak adalah adanya paradigma yang selama ini dianut oleh sebagian besar masyarakat bahwa percuma membayar pajak karena akan memperkaya petugas pajak. Tindakan seperti ini dilakukan masyarakat untuk meloloskan diri dari pajak dan merupakan usaha yang disebut perlawanan terhadap pajak. Perlawanan ini terbagi manjadi dua, yaitu: Perlawanan pasif dan Perlawanan aktif.

b. Untuk mengatasi permasalahan atau kendala tersebut, maka pemerintah harus dapat: $\mathrm{M}$ Menunjukkan kepada publik bahwa pengelolaan pajak dilakukan dengan baik dan benar, menyiapkan pengelolaan data yang lengkap, akurat, terintegrasi dan terjamin kerahasiannya (database management system), penyempurnaan perangkat aturan, melaksanakan penegakkan hukum secara konsisten dan tegas, Fiskus harus melayani Wajib Pajak secara professional, sosialisasi yang bersifat kontinyu,
Dirjen pajak perlu membentuk suatu team work guna mencari isu-isu strategis yang berkembang dan melakukan evaluasi terhadap isu tersebut (faktor ekternal), inovasi dalam palayanan, seperti kemudahan dan kenyamanan dalam mengurus pajak, syarat-syarat pemungutan pajak harus didasarkan: Pemungutan pajak harus adil, tidak menggangu perekonomian, Apabila langkah ini telah dilakukan, maka kepercayaan masyarakat pun meningkat, kemudian masyarakat akan tergerak hatinya untuk menyisihkan sebagian hartanya kapada negara dalam bentuk membayar pajak.

\section{Saran}

a. Pemerintah harus dapat: Menunjukkan kepada publik bahwa pengelolaan pajak dilakukan dengan baik dan benar, menyiapkan pengelolaan data yang lengkap, akurat, terintegrasi dan terjamin kerahasiannya (database management system), penyempurnaan perangkat aturan, melaksanakan penegakkan hukum secara konsisten dan tegas, Fiskus harus melayani Wajib Pajak secara professional, sosialisasi yang bersifat kontinyu

b. Dirjen pajak perlu membentuk suatu team work guna mencari isu-isu strategis yang berkembang dan melakukan evaluasi terhadap isu tersebut (faktor ekternal)

c. Melakukan inovasi dalam palayanan, seperti kemudahan dan kenyamanan dalam mengurus pajak 


\section{DAFTAR PUSTAKA}

\section{A. Buku}

Erly Suandy, Hukum Pajak, Edisi 5,

Jakarta: Salemba Empat, 2011.

Fidel, Pajak Penghasilan. Jakarta:

Carofin Publishing, 2008.

Jajat Djuhadiat S, Modul DPT III Pengantar Hukum Pajak, Jakarta : Departemen Keuangan-BPLK, 1993.

Mardiasmo, Perpajakan Edisi Revisi, Yogyakarta: CV Andy Offset, 2008.

Muqodim, Perpajakan Buku Satu, Yogyakarta: UII Press, 1999.

Mustaqiem, Pajak Daerah dalam

Transisi Otonomi Daerah, Jakarta:

FH UII Press, 2008.

R. Santoso Brotodihardjo, Pengantar Ilmu Hukum Pajak, Bandung : PT. Refika Aditama, Cet ke 21, 2008.

Rochmat Soemitro, Pengantar Singkat Hukum Pajak, Cetakan-2, Bandung : PT. Eresco, 1988.

Wirawan B.Ilyas \& Richard Burton, Hukum Pajak Edisi 3, Jakarta: Salemba Empat, 2007.

\section{B. Peraturan Perundang-undangan}

Undang - undang No. 6 Tahun 1983

Tentang Ketentuan Umum dan Tata Cara Perpajakan Sebagaimana Telah Diubah Dengan Undang-undang Nomor 16 Tahun 2009. 